\title{
Perubahan Dan Keberlanjutan Tari Balanse Madam Di Lingkungan Masyarakat Nias Padang
}

\author{
NOVINA YENI FATRINA ${ }^{1}$, YAN STEVENSON ${ }^{2}$ \\ 1,2. Prodi Televisi dan Film, Fakultas Seni Rupa dan Desain, ISI Padangpanjang \\ Jl. Bahder Johan, Padangpanjang, 27128, Indonesia \\ E-mail : novinapru@yahoo.co.id
}

\begin{abstract}
Tulisan berjudul "Perubahan dan Keberlanjutan Tari Balanse Madam di Lingkungan Masyarakat Nias Padang“ bertujuan untuk mengungkapkan perubahan tari Balanse Madam serta menganalisis keberlanjutannya. Tari Balanse Madam merupakan tarian kelompok yang terdiri dari pasangan penari laki-laki dan perempuan yang sudah menikah. Penampilannya diiringi secara live dengan alat musik barat seperti biola, gitar, tamburin, akordeon, dan set drum. Namun setelah banyak para pelaku seninya yang meninggal dunia, sehingga tari Balanse Madam mengalami perubahan. Perubahan terjadi pada penarinya, tidak harus orang yang sudah berumahtangga lagi, sedangkan musik iringannya no use life music. Analisa perubahan tari Balanse Madam diamati dari tahun 1995 sampai tahun 2017. Metode penelitian deskripsi kualitatif dengan pendekatan interaksi dan interpretasi analisis digunakan untuk mengungkapkan permasalahan tersebut. Pelacakan dilakukan dengan melihat dan menganalisa perubahan tari Balanse Madam pada perkembangan elemen pembentuk komposisi tarinya dari tahun 1995 sampai tahun 2017. Penelitian perubahan dan keberlanjutan tari Balanse Madam di lingkungan masyarakat Nias Padang dianalisis dengan menggunakan teori ketahanan budaya yang dikemukakan oleh Edi Sedyawati dan teori elemen pembentuk komposisi yang digunakan oleh R.M. Soedarsono. Hasil penelitian menunjukan bahwa seiring dengan berjalannya waktu, berbagai hal mempengaruhi kondisi tari Balanse Madam, sehingga terjadi perubahan pada beberapa elemen pembentuk tari Balanse Madam. Adapun perubahan tersebut adalah (1) penari terdiri orang-orang yang masih remaja; (2) musik iringan mengalami perubahan irama dan terkadang diiringi musik rekaman. Pemakaian penari remaja dan musik rekaman merupakan salah satu bentuk keberlanjutan tari Balanse Madam. Inilah yang membuat tari Balanse Madam masih tetap bertahan dalam kehidupan masyarakat Nias Padang.
\end{abstract}

Kata kunci : perubahan, keberlanjutan, tari balanse madam

The article entitled "The Change and Sustainability of Balanse Madam Dance in the Nias Padang Community" aims to reveal Balanse Madam dance changes and to analyze its sustainability. After many of its supporting artists died, many changes occurred in Balanse Madam dance, both in terms of dancers as well as the music of the accompaniment. Qualitative description research method with the approach of interaction and interpretation analysis was used to reveal this problem. The tracking was done by way of viewing and analyzing Balanse Madam dance changes on the development of forming elements in dance compositions from 1995 to present. The study of change and sustainability of Balanse Madam dance in Nias Padang society was analyzed by using culture endurance theory proposed by Edi Sedyawati and the theory of composition forming elements used by R.M. Soedarsono. The study results showed that over time, various things affect the condition of Balanse Madam dance, resulting in changes in some elements of Balanse Madam dance formation. The changes are (1) the dancers, who used to be housewives, can now be performed by the dancers that are still teenagers; (2) music accompaniment, used to be played directly by musicians, but now can be accompanied by music recordings. The use of teen dancer and music recordings are a form of sustainability carried out in Balanse Madam dance.

Keywords : change, sustainability, balanse madam dance

Peer Review : 2 - 19 Januari 2018, Acepted to Publish 22 Januari 2018 


\section{PENDAHULUAN}

Tari Balanse Madam merupakan salah satu kesenian yang dimiliki oleh masyarakat Nias di Padang atau yang kemudian dikenal dengan sebutan Nias Padang. Keberadaan tari Balanse Madam sangat unik di antara kesenian tradisi yang ada di kota Padang. Keunikannya membedakan tari Balanse Madam dengan tari-tari di kota Padang. Perbedaan dapat dilihat pada vokabuler gerak tarinya. Tari Balanse Madam mirip dengan jenis joget dari kesenian Melayu yang menggunakan vokabuler gerak langkah lenggang sebagai gerak baku. Berbeda dengan vokabuler gerak tari tradisi di kota Padang, umumnya berdasarkan kepada gerak pencak silat dan gerak imitasi pada alam (Edi Sedyawati, 1981:73).

Keunikan lainnya adalah bahwa tari Balanse Madam dimainkan oleh empat, delapan atau enam belas pasangan penari pria dan wanita. Para penarinya adalah orang yang sudah berumah-tangga dan harus mendapat izin dari pasangannya suami atau istri (Novina Yeni Fatrina, 2009:1). Di antara penari laki-laki ada salah satunya bertindak sebagai comander yaitu orang yang memberi aba-aba gerak atau perintah kepada para penari, sekaligus mengatur jalannya penampilan tari Balanse Madam. Setiap perubahan pola lantai dan bentuk gerak selalu diawali dengan aba-aba yang diperintahkan oleh comander. Selain itu, formasinya berbentuk segi empat; pasangan yang satu saling berhadapan dengan pasangan lainnya dengan pemakaian pola lantai mirip dengan The Quadrille, yaitu nama satu tarian yang bercorak dansa di Perancis pada tahun 1819 (Novina Yeni Fatrina, 2009:2).

Penampilan tari Balanse Madam biasanya dimainkan dengan iringan alat musik barat seperti set drum, gitar, tambur, tamburin, biola dan akordion. Dimana biola memegang peranan penting dalam permainan tari Balanse Madam. Namun ada kelangkaan terhadap pemain musik iringan tari Balanse Madam, terutama pada pemain musik biola. Hal ini dikarenakan pemain musik biolanya mengalami penyakit stroke, sehingga tidak dapat memainkan alat musik biola. Alat musik biola tergolong mahal dan hanya dimiliki oleh orang tertentu saja. Selain itu, banyak pemain musik yang sudah tua bahkan telah meninggal, sedangkan generasi muda yang dapat memainkan iringan musik tari Balanse Madam belum banyak yang mahir (Novina Yeni Fatrina, 2009:170).

Akibat kondisi pemain musik yang demikian, sejak tahun 2009 itu iringan untuk musik tari Balanse Madam sudah mulai digantikan dengan menggunakan orgen tunggal. Pemakaian orgen tunggal pada tari Balanse Madam, tampaknya juga pengaruh dari semakin maraknya orgen tunggal digunakan sebagai musik hiburan pada acara pesta perkawinan, termasuk acara pesta perkawinan pada masyarakat Nias Padang. Dimana selera masyarakat terpenuhi ketika adanya kepraktisan penggunaan satu alat musik seperti orgen tunggal yang dapat mewakili banyak alat musik, sehingga dengan menggunakan orgen tunggal penampilan tari Balanse Madam tetap masih dapat diiringi. Kondisi demikian, pada satu sisi dapat melestarikan kesenian tersebut, tetapi disisi lain juga menghilangkan kekhasan wujud fisik penampilannya. Artinya terjadi kemerosotan dan pencemaran budaya pada iringan musik tari Balanse Madam. Sebagaimana yang dijelaskan oleh Kontowijoyo bahwa, "selera publik sering menjadi penyebab dekadensi, vulgarisasi dan pencemaran budaya" (Kuntowijoyo, 1987:29).

Selain pada pemain musik tari Balanse Madam, kelangkaan juga terjadi pada comander, yaitu penari laki-laki yang memberikan perintah atau aba-aba formasi gerak dalam penampilan tari Balanse Madam. Keberadaan comander sangat memegang peranan penting dan yang memberikan pembedaan dengan tari-tari di kota Padang. Pada tahun 1995, ada satu orang comander bernama Lulu Bôwồ Waruwu yang saat itu sudah berusia lanjut yaitu 62 tahun. Namun penelitian tahun 2009 yang penulis lakukan, Lulu Bôwồ Waruwu telah meninggal dan digantikan oleh salah seorang kerabatnya yang bernama Gusman Dawôlồ (45 tahun). Akan tetapi, pertengahan tahun 2015 Gusman Dawôlồ yang biasanya bertindak sebagai comander juga meninggal dunia, sehingga terjadi kekosongan pada posisi ini. Dengan demikian penggiat-penggiat tari Balanse Madam dikhawatirkan akan punah.

Melihat situasi yang demikian penulis tertarik untuk mengkaji lebih mendalam perubahan tari Balanse Madam pada perkembangan elemen pembentuk komposisi tarinya dari tahun 1995 sampai sekarang, baik dari segi pemain; penari dan pemusiknya, gerak tari dan desain lantainya, rias dan busana tari Balanse Madam. Agar tujuan yang diharapkan dapat tercapai dengan baik, maka dirumuskan permasalahan dalam penelitian ini, yaitu: bagaimana perubahan bentuk penampilan tari Balanse Madam dari tahun 1995 sampai saat usulan penelitian ini dilakukan, serta bagaimana keberlanjutan tari Balanse Madam setelah banyak para seniman pendukungnya meninggal dunia.

Begitu kompleks permasalahan yang akan diungkapkan dari perubahan dan keberlanjutan tari Balanse Madam, maka penelitian ini memakai teori ketahanan budaya yang dikemukakan oleh Edi Sedyawati, bahwa ketahanan budaya dapat diartikan sebagai "ti- 
dak goyah" atau "tidak bergeming". Ada dua golongan hal yang mempunyai potensi demikian. Pertama, adanya dorongan-dorongan perubahan yang datang dari masyarakat pendukung kebudayaan itu sendiri, baik yang disebabkan oleh faktor alami maupun karena adanya naluri perintis dan mampu mengaktualisasikannya. Kedua, pengaruh-pengaruh dari luar kebudayaan yang bersangkutan. Pengaruh tersebut disebabkan oleh adanya interaksi antara bangsa. Interaksi terjadi bila ada tatap muka antara orangorang dari kebangsaan yang berbeda (Edi Sedyawati, 2007:35-36). Adapun untuk menganalisis perubahan elemen pembentuk komposisi tari Balanse Madam, penulis memakai teori R.M. Soedarsono (1978) yang dibatasi pada analisa pemain; penari dan pemusiknya, gerak tari dan desain lantai, rias dan busananya.

Penelitian ini bertujuan untuk mencari jawaban dari permasalahan yang telah dirumuskan di atas, yaitu mengungkapkan perubahan bentuk penampilan tari Balanse Madam dari tahun 1995 sampai saat usulan penelitian ini dilakukan, serta menganalisa keberlanjutan tari Balanse Madam setelah banyak para seniman pendukungnya meninggal dunia. Dengan dilakukan penelitian ini, diharapkan dalam jangka panjang, pada tahap awal dilakukan inventarisasi, identifikasi dan pemetaan terhadap keberadaan tari Balanse Madam saat sekarang, sedangkan tahap berikutnya adalah pelatihan dan pembinaan, sehingga diharapkan kedepannya pertunjukan tari Balanse Madam tetap eksis dimainkan dengan iringan alat musik barat dan tetap menghadirkan comander, sehingga tidak menghilangkan kekhasan dari tari Balanse Madam. Pada akhirnya melalui tari Balanse Madam masyarakat Nias Padang mendapatkan identitas budayanya.

\section{METODE PENELITIAN}

Tulisan ini membahas perubahan bentuk penampilan tari Balanse Madam dan keberlanjutannya setelah banyak penggiat atau pelaku seninya yang meninggal dunia. Data tulisan ini didapatkan dari studi pustaka pada laporan penelitian berupa tesis yang berjudul "Tari Balanse Madam Pada Masyarakat Nias di Padang Sumatera Barat: Kajian Komparasi Bentuk", dan media internet yang mempublikasikan tentang eksistensi tari Balanse Madam di kota Padang di tiga tahun terakhir dari penelitian ini dilaksanakan. Selain itu, observasi dilakukan ke tempat penggiat dimana tari Balanse Madam ini dilatihkan kepada generasi penerusnya. Kemudian wawancara dilakukan kepada penggiat-penggiat yang masih eksis menghidup-kembangkan tari Balanse Madam.

\section{HASIL DAN PEMBAHASAN}

\section{Tari Balanse Madam Pemersatu dalam Adat}

Tari Balanse Madam merupakan tari pergaulan, sehingga dalam penerapannya dimainkan pada acara-acara perhelatan keadatan, antara lain: pengangkatan kepala kampung, pesta pernikahan, dan acara perhelatan-perhelatan nagari. Penempatan tari Balanse Madam di dalam acara-acara perhelatan ini, selain sebagai sarana hiburan juga merupakan suatu media interaksi sosial dari berbagai kalangan masyarakat Nias Padang. Bahkan ketika penampilan tari Balanse Madam yang diawali musik Gamad dengan lagu Kaparinyo, tidak saja dimainkan dan dihadiri oleh masyarakat Nias saja, akan tetapi pemain musiknya ada juga yang berasal dari keturunan orang Keling. Hal ini menunjukkan bahwa melalui penampilan tari Balanse Madam proses interaksi sosial dapat saja terjadi. Bentuk-bentuk interaksi sosial terjadi apabila orang-orang perorangan maupun kelompok-kelompok manusia mengadakan hubungan satu sama lainnya, terutama dengan mengetengahkan kelompok serta lapisan sosial sebagai unsur pokok struktur sosial (Soerjono Soekanto, 2012:54).

Pertemuan masyarakat Nias Padang dalam acara perhelatan, baik pada pengangkatan kepala kampung, pesta pernikahan, dan acara perhelatan-perhelatan nagari, dengan suguhan acara hiburan seperti tari Balanse Madam, menjadi momen untuk mempererat hubungan silahturahmi. Agaknya ini dipicu dengan kondisi masyarakat Nias Padang bertempat tinggal tidak hanya pada satu tempat saja, melainkan mereka menyebar di tiga kecamatan di kota Padang, yaitu Padang Utara, Padang Selatan, dan Padang Barat. Meskipun demikian, mereka dipersatukan dalam acara-acara adat pada momen pertunjukan tari Balanse Madam.

Sebelum penampilan tari Balanse Madam ada persyaratan yang harus dipenuhi, yaitu permintaan izin untuk melaksanakan tari Balanse Madam dari tuo kafo yang bertindak sebagai janang, kepada kafalo kafo. Persyaratan tersebut terdiri dari seperangkat carano lengkap dengan isinya, yaitu berupa daun sirih, pinang, gambir, sadah, tembakau, kadang dilengkapi dengan rokok dan uang satu ringgit. Selain seperangkat carano lengkap dengan isinya, juga disertakan minuman tuo nifarô atau sofi atau minuman tuak. Jika persyaratan tadi sudah lengkap, diberikan kepada kafalo kafo. Seandainya minuman itu diterima, maka ditandai dengan meminum tuo nifarô secara bergiliran dari orang yang dituakan, yaitu kafalo kafo, tuo kafo, ninik mamak dan pemuka masyarakat.

Minum tuo nifarồ yang digunakan sebelum penampi- 
lan tari Balanse Madam telah menjadi adat dan tradisi di kalangan masyarakat Nias Padang. Agaknya budaya minuman yang dapat memabukkan jika diminum berlebihan ini adalah pengaruh budaya Eropa. Menurut Ben Suharto budaya minum seperti ini,

Sekilas adat kebiasaan semacam itu (minuman keras) berasal dari Barat, yang dibawa ketika zaman penjajahan. Di Eropa yang berhawa dingin sangat diperlukan minuman penghangat badan yang sangat penting pula bagi kesehatan. Bukan merupakan hal yang aneh bila mereka mempunyai adat kebiasaan minum-minuman keras, baik dalam keluarga, maupun dalam setiap pertemuan, pesta dan sebagainya (Ben Suharto, 1999:58-59).

Penggunaan minuman tuo nifarö dalam rangkaian penampilan tari Balanse Madam, dapat diartikan sebagai sarana kebersamaan kaum adat Nias Padang, sehingga diharapkan dapat menjaga, mempererat rasa kekeluargaan dan persaudaraan dalam adat.

\section{Bentuk Penyajian Tari Balanse Madam}

Penyajian tari Balanse Madam sangat unik jika dibandingkan dengan tari-tari yang ada di kota Padang. Keunikan penyajian tari Balanse Madam dilihat secara utuh dari elemen pembentuknya. Dimana elemen pembentuk dalam sebuah tarian merupakan suatu struktur yang tidak dapat dipisah-pisahkan. Sebagaimana yang dikatakan oleh Soedarsono tentang elemen pembentuk tari.

Ada cukup banyak elemen-elemen pembentuk komposisi sebuah tari, yaitu gerak tari, desain lantai, desain atas, desain musik, desain dramatik, koreografer kelompok, tema, rias dan busana, properti tari, pementasan, tata lampu, dan penyusunan acara. Akan tetapi, elemen-elemen tersebut hanya untuk jenis komposisi tari pertunjukan. Berbeda untuk tari bergembira yang lazim disebut tari sosial. Banyak faktor-faktor yang bertentangan dengan tuntutan koreografi tari pertunjukan. Pada tari bergembira, teknik tari seorang penari tidak begitu penting. Asal ia bisa bergerak seirama dengan musiknya dan diikuti dengan langkah kaki yang betul, itu sudah cukup (R.M. Soedarsono,1978:21-22).

Berdasarkan pendapat Soedarsono di atas, maka tari elemen pembentuk komposisi tari Balanse Madam yang dapat dibicarakan hanya beberapa elemen tari saja, yaitu pemain (penari dan pemusik), gerak tari, desain lantai/ pola lantai, rias dan busana serta tempat pertunjukannya.

\section{Penari}

Para penari tari Balanse Madam berbeda dengan kebanyakan penari tari di kota Padang. Biasanya sebuah tarian dibawakan oleh para penari wanita atau laki-laki yang masih muda saja; atau penari wanita atau laki-laki yang sudah tua saja; atau penari berpasangan. Namun pada penyajian tari Balanse Madam, ada ketentuan untuk para penarinya, yaitu pasangan laki-laki dan perempuan yang harus sudah menikah atau berumahtangga, tetapi tidak dibolehkan ikut pasangan suami istri. Kemudian penari yang ikut berpartisipasi menarikan tari Balanse Madam harus mendapatkan izin dari pasangannya (suami atau istri).

Penari yang diikutsertakan dalam penampilan tari Balanse Madam, adalah yang ditunjuk oleh tuo kafo atau janang, karena dipercaya sudah dapat menarikan tari Balanse Madam. Tuo kafo akan menentukan jumlah penari, mulai dari yang paling sedikit empat pasangan penari, delapan pasangan penari, atau enambelas pasangan penari. Jumlah penari disesuaikan dengan besarnya tempat yang tersedia. Selain itu, di antara pasangan penari laki-laki dan perempuan terdapat penari laki-laki yang yang bertugas sebagai comander.

Comander adalah orang yang memberi perintah atau aba-aba untuk setiap perubahan desain lantai. Artinya, dengan aba-aba yang diucapkan comander, maka para penari akan dipandu untuk membentuk perubahan desain lantai dan pola gerak. Namun comander bisa saja tidak ikut dalam rombongan penari, akan tetapi dia berada di luar penari dan ikut berdiri dengan rombongan pemusik. Menurut Tawanto, aba-aba yang diberikan comander mereka yakini dalam bahasa Portugis (Tawanto Karim, wawancara April 2017).

\section{Pemusik}

Penampilan tari Balanse Madam diiringi alunan dari alat-alat musik Eropa, seperti: biola, gitar, tambur, tamburin, set drum, dan akordion. Namun yang memegang peranan penting dari sederetan alat musik itu adalah biola, karena iringan tari Balanse Madam sangat tergantung kepada irama musik biola (Novina Yeni Fatrina, 2009:118). Pentingnya permainan musik biola dikarenakan alat musik iringan tari Balanse Madam sama dengan musik gamad. Gamad, yaitu gabungan dari berbagai alunan musik daerah seperti Medan, Melayu, Portugis dan Minangkabau. Dalam musik gamad dikenal dua macam tempo yaitu langgam dan joget. Langgam untuk lagu lambat dan joget untuk lagu dengan tempo cepat (Rizaldi dalam Novina Yeni Fatrina, 2009:4). Oleh karena itu, iringan musik Balanse Madam termasuk kepada musik joget. 
Pada saat ini sangat disayangkan, banyak pemain musik tari Balanse Madam sudah tua dan sakit-sakitan, bahkan ada juga yang sudah meninggal, termasuk pemain musik biola. Meskipun demikian penggiat tari Balanse Madam mencoba meregenerasikan pemain musik, khusus pemain biola. Namun usaha yang dilakukan belum mencapai hasil sesuai harapan, karena disebabkan oleh beberapa faktor. Salah satu faktornya adalah sulit untuk mendapatkan pengganti pemain musik biola. Tidak banyak orang Nias yang punya alat musik biola, karena dianggap alat musik mahal. Selain itu, untuk memainkan alat musik biola ini perlu latihan khusus.

Kelangkaan pemain musik untuk iringan tari Balanse Madam, menyebabkan pertunjukan tari Balanse Madam sering diiringi permainan orgen tunggal. Pemakaian orgen tunggal sebagai alat musik pengganti bagi keberadaan alat musik gitar, set drum, tambur, tamburin, akordion, bahkan biola, agaknya disebabkan adanya kepraktisan yang terdapat orgen tunggal. Hanya dengan menggunakan satu alat musik seperti orgen tunggal saja, sudah dapat mewakili semua alat musik. Selain itu, keberadaan orgen tunggal sebagai pengganti alat musik tari Balanse Madam juga seiring dengan maraknya penggunaan orgen tunggal untuk acara hiburan di tempat-tempat baralek atau pesta pernikahan di kota Padang.

Selain pemakaian orgen tunggal, iringan tari Balanse Madam terkadang merisaukan hati para penggiatnya. Jika ada permintaan pertunjukan tari Balanse Madam, sementara pemain biola sedang tidak ada di tempat atau tidak dapat hadir, maka penggiat tari Balanse Madam dengan terpaksa menyiapkan musik rekaman melalui flashdisk sebagai alternatif. Sebagaimana kita ketahui, bahwa flashdisk merupakan salah satu media untuk menyimpan data, baik berupa data tertulis, gambar/ visual, maupun data suara. Melalui flashdisk rekaman iringan musik seperti tari Balanse Madam dapat disimpan dan diputar kembali.

\section{Gerak Tari}

Setiap tarian daerah ataupun tari dari suatu kelompok masyarakat mempunyai kekhasannya masing-masing. Suatu kelompok masyarakat akan diketahui bentuk kebudayaannya melalui sebuah tari. Tari adalah salah satu pernyataan budaya, maka sifat, gaya, dan fungsinya selalu tak dapat dilepaskan dari kebudayaan yang menghasilkannya (Edi Sedyawati, 1986:3). Demikian juga dengan tari Balanse Madam, masyarakat pendukungnya adalah kelompok masyarakat Nias Padang.

Berdasarkan tempat tinggalnya, kelompok masyarakat Nias Padang banyak tinggal di daerah pesi- siran pantai Sumatera Barat yang berdekatan dengan perbukitan dan pelabuhan. Secara geografis daerah pesisiran pulau Sumatera Barat sempat menjadi pintu gerbang perdagangan bagi bangsa asing seperti Eropa, Arab dan Cina untuk memasuki Minangkabau. Hal ini memungkinkan terjadinya persentuhan budaya asing dengan masyarakat pribumi di pesisir pantai Sumatera Barat. Persentuhan budaya antara bangsa asing dan pribumi berpeluang untuk saling take and give budaya, bahkan saling meniru satu dengan yang lainnya, termasuk musik dan tarian. Sebagaimana Portugis termasuk bangsa Eropa yang pernah berada di Padang. Rusli Amran dalam tulisannya menjelaskan, dalam laporan Mac Gillavry, bahwa tari Balanse sebagai peninggalan Portugis digemari oleh rakyat di Padang, termasuk suku Nias (Novina Yeni Fatrina, 2009:94). Namun dalam realitanya sekarang, yang menjadi pendukung tari Balanse Madam adalah masyarakat Nias Padang.

Keberadaan tari Balanse Madam ditengah-tengah kehidupan masyarakat Nias Padang, jika dikaitkan dengan geografis tempat tinggal masyarakat Nias Padang, berada di daerah pesisir pantai Sumatera Barat. Oleh sebab itu, maka gaya tari Balanse Madam mencerminkan kehidupan masyarakat pesisir. Seni tari yang berkembang adalah tarian sosial, sehingga lebih bermakna kepada tari pergaulan dan kebersamaan. Hal ini terwujudkan ketika tari Balanse Madam berlangsung. Melalui gerak-gerak yang dibawakan oleh para penari, memperlihatkan gerak tari Balanse Madam termasuk kepada jenis tari joget seperti tarian Melayu. Gerak tari Melayu jenis joget yang ditampilkan penggiat tari Balanse Madam lebih memperlihatkan kepada gerak-gerak langkah lenggang, yaitu antara langkah kaki dengan ayunan tangan seperti orang berjalan yang melangkah seirama dengan alunan musik. Sekali-sekali bentuk gerak tangan berubah sesuai dengan aba-aba yang diberikan comander. Adakalanya tangan pasangan penari laki-laki dan perempuan bersentuhan dengan pasangannya sendiri seperti bergandengan tangan. Namun sekali-sekali bergandengan dengan pasangan lainnya, atau sebaliknya sesama jenis penari laki-laki atau penari perempuan bersentuhan seperti bersalaman dalam pola melingkar berhadapan.

Dalam satu artikel Yulianti L. Parani, mengatakan bahwa joget adalah sebuah tarian meriah, dengan rentak yang agak laju. Tarian ini, dipersembahkan oleh pasangan penari dengan gerak-gerik pantas yang disulami pelbagai usikan, berasal dari tarian tradisi Portugis yang diperkenalkan di Melaka sewaktu era perdagangan rempah di situ (http://pmr.penerang-an. gov.my/index.php/budaya/3247-tarian-melayu.html, diakses 12 September 2017). 
Akan tetapi, penulis melihat gerak tari Melayu jenis joget yang ditampilkan penggiat tari Balanse Madam lebih memperlihatkan kepada gerak-gerak langkah lenggang, yaitu antara langkah kaki dengan ayunan tangan seperti orang berjalan dengan tempo cepat (marcia) dan melangkah seirama dengan alunan musik. Di dalam tari Balanse Madam bentuk gerak tangan sekali-sekali berubah sesuai dengan aba-aba yang diberikan comander. Adakalanya tangan pasangan penari laki-laki dan perempuan bersentuhan dengan pasangannya sendiri seperti bergandengan tangan. Namun sekali-sekali bersentuhan ujung jari tangan dengan pasangan lainnya, atau sebaliknya sesama jenis penari laki-laki atau penari perempuan bersentuhan seperti bersalaman dalam pola melingkar berhadapan.

\section{Desain Lantai}

Perubahan setiap desain lantai tari Balanse Madam diawali dengan aba-aba dari comander. Dimana penari laki-laki yang biasa disebut tuan dan penari perempuan disebut madam akan bergerak sesuai abaaba dari comander. Setelah aba-aba penari bergerak mengubah desain lantai, kemudian sambil bergerak ujung jari tangan penari bersentuhan sebentar saja. Jika putarannya ke arah kanan maka tangan kanan yang bertemu, sedangkan putaran arah kiri maka tangan kiri yang bertemu. Adapun desain lantai yang digunakan dalam menarikan tari Balanse Madam, adalah desain lantai yang cenderung dibuat dalam bentuk melingkar. Penampilan tari Balanse Madam terdiri dari empat, delapan sampai enambelas pasangan penari. Namun penjelasan desain lantai pada tulisan ini memberikan gambaran desain lantai untuk empat pasangan penari. Ada beberapa desain lantai yang dibentuk dalam tari Balanse Madam sesuai dengan aba-abanya, antara lain:

Pola dasar; merupakan posisi yang cenderung dibentuk dalam tari Balanse Madam, yaitu posisi empat penjuru dengan formasi saling berhadapan. Misalkan pasangan penari A berhadapan dengan pasangan penari $\mathrm{C}$ disebut bagian kepala, sedangkan pasangan penari $\mathrm{B}$ berhadapan dengan pasangan penari $\mathrm{D}$ disebut bagian rusuk. Penari perempuan berada di kiri penari laki-laki.

Oplas kare; semua pasangan penari melangkah ke tengah sambil berpegangan tangan, sehingga pasangan bagian rusuk berpegangan dengan pasangan bagian kepala. Bertemu di tengah kemudian mundur kembali ke posisi semula.

Oplas; bersiap-siap untuk menari.

Balanse madam; setiap madam menari dengan tuan.
Balanse agus; madam menari dengan tuan dari pasangan lain yang berada disebelah kanan madam (madam dibagian kepala menari dengan tuan dibagian rusuk, sedangkan tuan dibagian kepala menari dengan madam dibagian rusuk.

Inggirland; kembali menari dengan pasangan masing-masing atau kembali ke posisi semula.

Turdiman; semua tuan maju ke tengah lingkaran, kemudian memutar arah hadap ke kiri sehingga tuan dan madam saling berhadapan.

Lepasture; lepaskan pegangan tangan madam.

Alvangka inkua diso; pasangan penari diposisi kepala A dengan kepala B menari ke tengah, sementara pasangan penari diposisi rusuk A dan rusuk B melenggang di tempat.

Bulne; pasangan penari yang berada di tengah lingkaran mempertemukan ujung kedua tangan seperti bersalaman gaya adat Jawa; tuan dengan tuan dan madam dengan madam.

Timarfarti alafikat; pasangan penari diposisi kepala A dn kepala B bersiap-siap menari ke tengah. Sementara pasangan penari rusuk A dan rusuk B melakukan gerak melenggang di tempat.

Saina aiglas madam; semua pasangan penari berkumpul ke tengah dengan membentuk dua lingkaran dan saling berpegangan tangan; lingkaran madam berada dibagian dalam berputar ke kanan mengikuti lingkaran, sedangkan lingkaran tuan mengelilingi lingkaran madam dengan berputar ke kiri mengikuti/ berlawanan arah dengan putar madam.

Saina adida madam; madam yang dibagian rusuk bertemu dan bertukar tempat dengan berjalan ke tengah lingkaran, kemudian mempertemukan kedua telapak tangannya dengan tinggi sebatas kepala, lalu berjalan kembali ke arah tuan masing-masing.

Saina aiglas; pasangan penari rusuk saling berpegangan tangan dengan madam menghadap keluar lingkaran dan tuan menghadap ke dalam lingkaran

Virduba; pasangan penari kepala melangkah berkeliling dengan menyamping searah jarum jam

Romdikate; pasangan yang menari ke tengah berpegangan tangan, berkeliling melangkah menyamping searah jarum jam dengan arah hadap penari ke dalam lingkaran, sementara pasangan penari yang berada disisi lainnya melakukan gerak melenggang di tempat. 


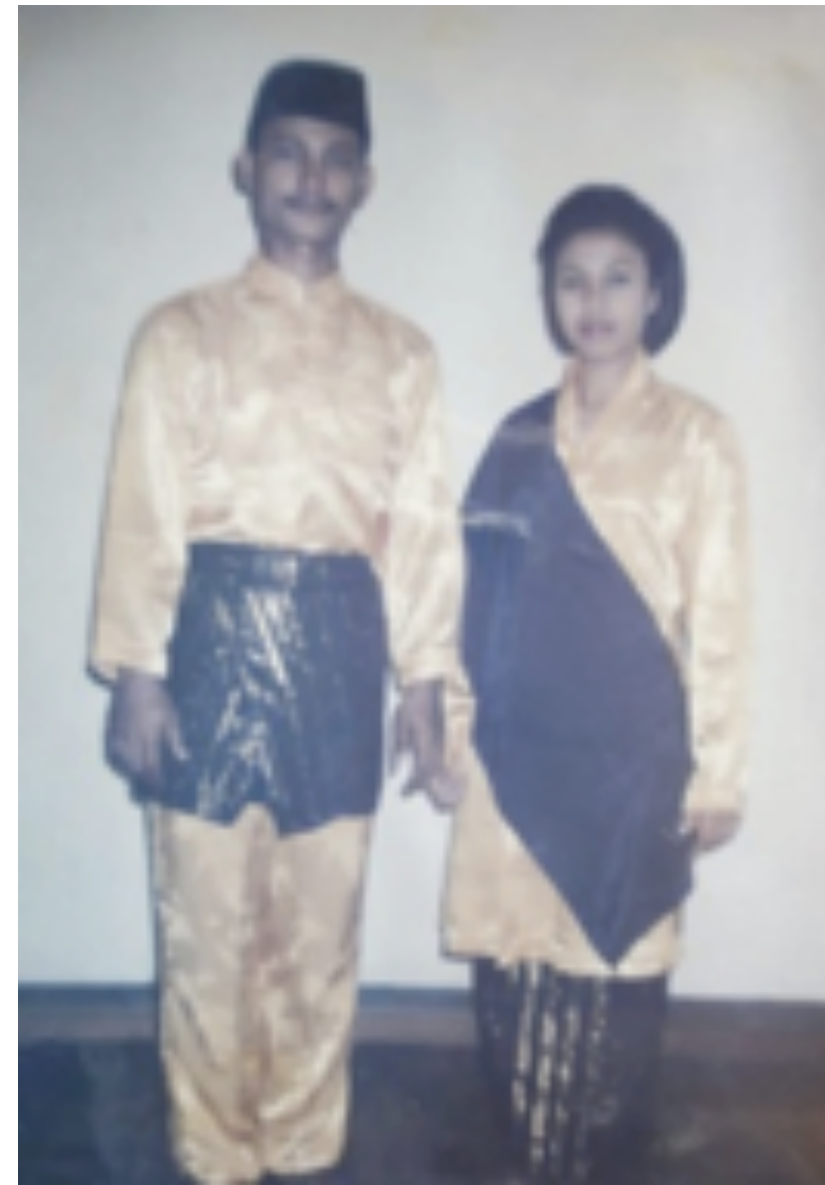

Gambar 1. Busana Penari

(Foto repro: Novina Yeni Fatrina, 2017)

Saini coprit; tuan di bagian kepala bertukar tempat dengan berjalan ke tengah, kemudian mempertemukan kedua tangannnya sebatas kepala dan jalan satu kali putaran lalu memutar arah hadap ke madam masing-masing (pasangan awal).

$\boldsymbol{R e}$; kembali gerak sebelumnya atau

Alvangka inkua diso agus adarlan; pasangan bagian rusuk menari dengan pasangan bagian kepala sehingga terbentuk kelompok-kelompok yang terdiri dari dua pasang penari.

Intuimar; pertunjukan balanse madam selesai, tuan mengandeng tangan madam dan keluar pentas.

Desain lantai yang cenderung dibentuk dalam posisi melingkar pada tari Balanse Madam memberikan gambaran bahwa masyarakat Nias Padang selalu menciptakan kebersamaan dan suasana kekeluargaan dalam kehidupan masyarakat Nias Padang.

\section{Rias dan Busana}

Busana merupakan suatu media untuk menutup tubuh

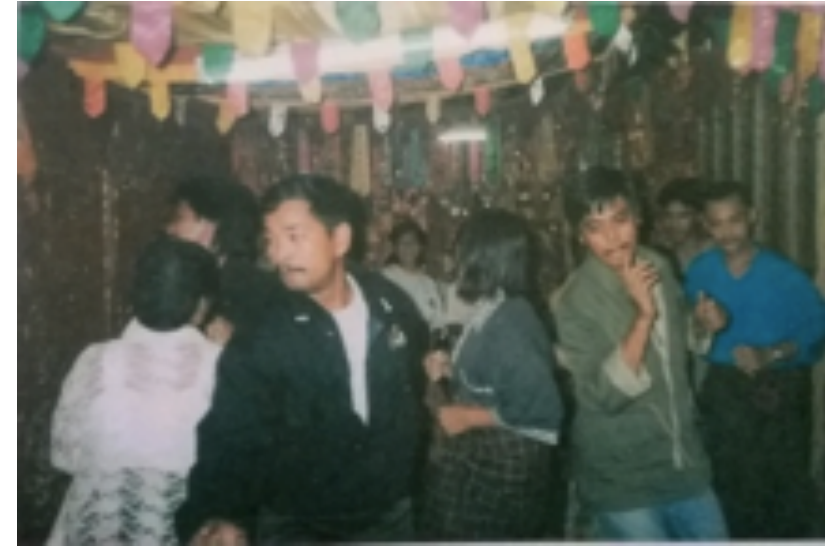

Gambar 2. Penampilan tari Balanse Madam di dalam ruangan.

(Foto repro: Martini, 2017)

seseorang. Namun selain sebagai penutup tubuh busana juga berperan mendukung penampilan. Melalui busana yang khas dapat diketahui dari mana si pemakai berasal, karena model dan gaya busana juga bisa menjadi identitas bagi seseorang atau suku bangsa. Demikian juga pemakaian busana pada penari tari Balanse Madam. Sehubungan dengan keberadaan tari Balanse Madam di kota Padang yang juga merupakan daerah bagian dari pengaruh Melayu, maka busana yang dikenakan para penari juga mencirikan kekhasan busana Melayu.

Busana yang digunakan untuk penampilan tari Balanse Madam terdiri dari busana stelan gunting cina untuk penari laki-laki dan kebaya panjang untuk penari perempuan (lihat gambar 1). Adapun riasan yang digunakan bagi penari adalah rias cantik sehari-hari untuk penari perempuan, sedangkan penari laki-laki dapat dikatakan tidak memakai riasan. Pemakaian riasan seperti ini juga berlaku dalam acara-acara perhelatan. Namun adakalanya, permintaan tari Balanse Madam tidak direncanakan, sehingga yang menarikannya menggunakan kostum apa yang mereka kenakan saat itu.

\section{Tempat Pertunjukan}

Tempat pertunjukan tari Balanse Madam sangat fleksibel dan tidak ada aturan yang mengikat, sehingga dapat dilaksanakan di ruang tertutup (di dalam ruangan) ataupun di tempat terbuka. Pelaksanaan tari Balanse Madam di ruang tertutup seperti acara pernikahan biasanya dilaksanakan di depan pelaminan pengantin dan jumlah penarinya hanya empat pasangan penari. Jumlah ini merupakan jumlah pasangan penari yang terkecil (lihat gambar 2). Sementara pelaksanaan di tempat terbuka adalah di luar rumah dengan jumlah penari dapat lebih dari empat pasangan penari. 


\section{Perubahan Elemen-elemen Tari Balanse Madam}

Penelitian ini bertujuan untuk mengungkapkan perubahan bentuk penampilan tari Balanse Madam dari tahun 1995 sampai saat usulan penelitian ini dilakukan. Berdasarkan jabaran pada bentuk penyajian tari Balanse Madam, terlihat ada perubahan. Perubahan itu terjadi pada pelaku tari (penari), abaaba comander, irama musik iringan, dan alat musik iringannya. Penyebab terjadinya perubahan itu tentu ada faktor yang mempengaruhinya. Teori perubahan yang dikemukakan oleh Alvin Boskoff, menjelaskan adanya perubahan disebabkan oleh faktor internal dan eksternal. Faktor internal adalah perubahan kebudayaan yang datang dari masyarakat pendukung kebudayaan itu sendiri, disebabkan karena berbagai macam dorongan, antara lain tantangan dari perubahan yang sifatnya alami dan demikian bermaknanya perubahan tersebut sehingga manusia didorong ke arah suatu keharusan untuk menyesuaikan diri. Faktor eksternal adalah pengaruh-pengaruh dari luar karena adanya interaksi, misalnya interaksi antara bangsa (1964:140-158).

Selain itu, perubahan dapat saja terjadi disebabkan goyahnya ketahanan budaya yang dimiliki oleh masyarakat pendukungnya. Edi Sedyawati menjelaskan bahwa.

Ketahanan budaya dapat diartikan sebagai "tidak goyah" atau "tidak bergeming". Namun ketahanan budaya dapat berubah karena ada dua sebab. Pertama, adanya dorongan-dorongan perubahan yang datang dari masyarakat pendukung kebudayaan itu sendiri, baik yang disebabkan oleh faktor alami maupun karena adanya naluri perintis dan mampu mengaktualisasikannya. Kedua, pengaruh-pengaruh dari luar kebudayaan yang bersangkutan. Pengaruh tersebut disebabkan oleh adanya interaksi antara bangsa (2007:35-36).

Hasil analisa terhadap perubahan tari Balanse Madam agaknya lebih cenderung kepada faktor internal. Hal ini terlihat pada perubahan pelaku tari (penarinya), irama musik iringan, dan alat musik iringannya. Perubahan pada pelaku tari (penari) disebabkan oleh beberapa faktor, antara lain: banyaknya pelaku tari telah meninggal dunia dan yang masih hidup juga sudah tua-tua, sehingga tidak sanggup untuk berdiri melakukan tari ini. Jika kondisi ini tidak segera ditanggapi, maka akan terjadi kepunahan. Akhirnya penggiat tari Balanse Madam mengambil sikap dengan memberikan kelonggaran pada aturan untuk penari Balanse Madam. Biasanya penari Balanse Madam hanya dimainkan oleh orang-orang yang sudah menikah atau berumahtangga. Akibat kondisi dari para penari yang tidak memungkinkan lagi untuk menari, maka dicarikan solusi, yaitu dengan membuat perubahan pada aturan bagi penari. Ada kelonggaran untuk aturan penari, yaitu dengan memberikan izin orang yang masih remaja sebagai penari Balanse Madam. Penari-penari dipilih dan dilatih, sehingga pada saat ada acara pesta mereka sudah bisa untuk menarikannya.

Selain perubahan terjadi pada penarinya, juga terjadi pada aba-aba yang diucapkan comander. Perubahan aba-aba ini disebabkan tidak banyak orang yang sanggup untuk mengelar tari Balanse Madam, karena membutuhkan biaya yang lumayan besar. Hal ini berdampak pada itensitas penampilan tari Balanse Madam menjadi jarang dipergelarkan. Bisa saja dalam satu tahun cuma digelarkan dua sampai tiga kali dalam setahun. Terakhir tari Balanse Madam ditampilkan pada bulan November tahun 2016 dengan comander yang masih baru dan muda, karena yang biasa menjadi comender telah meninggal dunia. Namun sebelum meninggal sudah mewarisi aba-aba tari Balanse Madam pada kedua putranya. Akan tetapi, daya ingat manusia tidak selamanya bekerja dengan baik. Jarangnya tari ini dimainkan, comender muda ini juga lupa-lupa ingat dengan aba-aba yang pernah dipelajarinya, tetapi bila dilatih lagi diyakini bisa kembali (Hafizd Zaldi (18 tahun), wawancara 27 Agus 2017). Ibarat pepatah Minang " lanca kaji dek diulang" artinya lancarnya suatu ilmu karena sering diulang atau digunakan. Inilah yang terjadi pada comander muda, karena kurangnya intensitas penampilan tari Balanse Madam dalam setahun sehingga bisa menjadi lupa. Melalui penelitian suatu budaya dapat direkam dan ditulis, sehingga menjadi dokumen yang bisa dibuka kapan saja. Berikut perubahan aba-aba yang terdapat pada tari Balanse Madam.

Perbedaan aba-aba ini menunjukan bahwa ada keterbatasan daya ingat manusia. Apabila ilmu atau kepandaian seseorang tidak diterapkan dalam jangka waktu yang lama, dapat membuatnya lupa dengan ilmu atau kepandaian yang dimilikinya. Inilah yang terjadi kepada comander tari Balanse Madam. Akibat jarangnya tari Balanse Madam ini ditampilkan sehingga dapat memberikan mempengaruh seperti terjadinya perubahan pada aba-aba tari Balanse Madam.

Perubahan lain juga terjadi pada musik iringan tari Balanse Madam. Sebagaimana yang telah disampaikan sebelumnya, bahwa yang memegang peranan penting dalam musik iringan tari Balanse Madam adalah irama dari musik biola. Mulai dari awal sampai berakhirnya penampilan tari Balanse Madam irama musik biola yang sangat berperan. Sementara pemain biola dari kalangan masyarakat Nias Padang yang dapat memainkan iringan musik tari Balanse Madam sangat langka. Kelangkaan ini pemain musik 
Tabel 1. Perbedaan dan persamaan aba-aba yang diberikan comander (Novina Yeni Fatrina, 2009:186)

\begin{tabular}{|c|c|c|c|c|}
\hline No & $\begin{array}{l}\text { Nama Aba- } \\
\text { aba }\end{array}$ & $\begin{array}{l}\text { Tahun } \\
1995 \\
\end{array}$ & $\begin{array}{l}\text { Tahun } \\
2016\end{array}$ & Keterangan \\
\hline 1 & Wib-wib mar & digunakan & tidak ada & Berbeda \\
\hline 2 & Damison & digunakan & tidak ada & Berbeda \\
\hline 3 & $\begin{array}{l}\text { Oplas kare } \\
\text { giram giro } \\
\text { inku inkua } \\
\text { kumpullima }\end{array}$ & digunakan & $\begin{array}{l}\text { oplas } \\
\text { kare }\end{array}$ & $\begin{array}{l}\text { Beda aba- } \\
\text { aba, gerak } \\
\text { sama }\end{array}$ \\
\hline 4 & Oplas & digunakan & $\begin{array}{l}\text { digu- } \\
\text { nakan }\end{array}$ & sda \\
\hline 5 & Lepasture & digunakan & $\begin{array}{l}\text { digu- } \\
\text { nakan }\end{array}$ & sda \\
\hline 6 & Turdiman & digunakan & $\begin{array}{l}\text { digu- } \\
\text { nakan }\end{array}$ & sda \\
\hline 7 & Inggirland & digunakan & $\begin{array}{l}\text { digu- } \\
\text { nakan }\end{array}$ & sda \\
\hline 8 & $\begin{array}{l}\text { Balanse } \\
\text { madam }\end{array}$ & digunakan & $\begin{array}{l}\text { digu- } \\
\text { nakan }\end{array}$ & sda \\
\hline 9 & Balanse agus & digunakan & $\begin{array}{l}\text { digu- } \\
\text { nakan }\end{array}$ & sda \\
\hline 10 & $\begin{array}{l}\text { Vikalovani } \\
\text { farti alfikat }\end{array}$ & digunakan & $\begin{array}{l}\text { Alvangka } \\
\text { inkua } \\
\text { diso }\end{array}$ & sda \\
\hline 11 & $\begin{array}{l}\text { Vikalovani } \\
\text { farti alfikat, } \\
\text { kembali }\end{array}$ & digunakan & tidak ada & Berbeda \\
\hline 12 & Bulne & digunakan & $\begin{array}{l}\text { digu- } \\
\text { nakan }\end{array}$ & $\begin{array}{l}\text { Bentuk ger- } \\
\text { ak sama }\end{array}$ \\
\hline 13 & Rumdikate & digunakan & $\begin{array}{l}\text { Rom- } \\
\text { dikate }\end{array}$ & sda \\
\hline 14 & Rekturne & digunakan & tidak ada & Berbeda \\
\hline 15 & Balanse qodri & digunakan & $\begin{array}{l}\text { Saina } \\
\text { aiglas }\end{array}$ & $\begin{array}{l}\text { Bentuk ger- } \\
\text { ak sama }\end{array}$ \\
\hline 16 & $\begin{array}{l}\text { Alvangka } \\
\text { ingkua diso }\end{array}$ & digunakan & Tidak ada & sda \\
\hline
\end{tabular}

\begin{tabular}{|l|l|l|l|l|}
\hline 17 & Vingka diso & digunakan & $\begin{array}{l}\text { timarfarti } \\
\text { alafikat }\end{array}$ & $\begin{array}{l}\text { Bentuk ger- } \\
\text { ak sama }\end{array}$ \\
\hline 18 & $\begin{array}{l}\text { Vingka diso, } \\
\text { kembali }\end{array}$ & digunakan & tidak ada & Berbeda \\
\hline 19 & Ra room & digunakan & Intuirmar & $\begin{array}{l}\text { Bentuk ger- } \\
\text { ak sama }\end{array}$ \\
\hline 20 & Virduba & tidak ada & $\begin{array}{l}\text { digu- } \\
\text { nakan }\end{array}$ & Berbeda \\
\hline 21 & $\begin{array}{l}\text { Saina adida } \\
\text { madam }\end{array}$ & tidak ada & $\begin{array}{l}\text { digu- } \\
\text { nakan }\end{array}$ & sda \\
\hline 22 & $\begin{array}{l}\text { Saina aiglas } \\
\text { madam }\end{array}$ & tidak ada & $\begin{array}{l}\text { digu- } \\
\text { nakan }\end{array}$ & sda \\
\hline 23 & $\begin{array}{l}\text { Saina coprit } \\
\text { tidak ada }\end{array}$ & $\begin{array}{l}\text { digu- } \\
\text { nakan }\end{array}$ & sda \\
\hline 24 & $\begin{array}{l}\text { Rek } \\
\text { agua adarlan }\end{array}$ & tidak ada & $\begin{array}{l}\text { nakan } \\
\text { digu- } \\
\text { digu- } \\
\text { nakan }\end{array}$ & sda \\
\hline & tidak ada & sda \\
\hline
\end{tabular}

biola ini dikarenakan pada masa lampau alat musik biola tergolong mahal, sehingga hanya beberapa saja yang memilikinya.

Kurangnya orang dikalangan masyarakat Nias Padang yang memiliki alat musik biola, tentu memungkinkan hanya beberapa orang saja yang dapat memainkannya. Padahal irama musik biola ini yang sangat memegang peranan dalam mengiringi tari Balanse Madam. Artinya, musik iringan tari Balanse Madam lebih dominan irama musik biola, sejak dari awal sampai berakhirnya penampilan dengan dua pola irama yang dimainkan secara berulang-ulang. Ada kejelasan pola-pola irama yang dimainkan oleh pemain biola, sehingga penari mengetahui kapan ia harus mulai untuk menarikan tari Balanse Madam. Dengan demikian pertunjukan tari Balanse Madam sangat tergantung dengan irama biola (Novina Yeni Fatrina, 2009:170).

Sebagaimana kenyataannya saat ini, pemain biola yang biasanya mengiringi penampilan tari Balanse Madam sudah meninggal. Pada waktu dilaksanakan penelitian ini tahun 2016, ditemukan irama musik biola yang berbeda untuk penampilan tari Balanse Madam. Irama musik biola terdengar pada awal dan ditengah-tengah permainan, kemudian dilanjutkan dengan permainan akor-akor dari musik orgen tung- 
gal. Seolah-olah irama musik biola hanya selingan dari iringan musik tari Balanse Madam. Perubahan irama musik biola ini membingungkan penari kapan harus mulai untuk menarikan. Apalagi para penari adalah anak muda yang masih baru dalam menarikan tari Balanse Madam. Perubahan yang sangat memprihatinkan adalah penggunaan musik rekaman berupa flashdisk untuk iringan tari Balanse Madam. Pemakaian flashdisk dilakukan jika keadaan terpaksa, apabila pemain biola tidak dapat hadir untuk mengiringi penampilan tari Balanse Madam.

\section{Keberlanjutan Setelah Kerapuhan Datang}

Keberadaan tari Balanse Madam saat dilakukan penelitian tahun 2016 ini, ibarat kerakap di atas batu, hidup segan matipun tidak mau. Artinya, tari ini masih hidup ditengah-tengah masyarakat pendukungnya Nias Padang, namun sudah jarang ditampilkan. Berbagai faktor dapat saja menjadi penyebabnya, diantaranya: (1) banyaknya pemain baik pemusik dan atau penari yang sudah tua-tua, sehingga tidak sanggup untuk menampilkan tari ini; (2) banyak juga pemainnya yang sudah meninggal dunia sebelum adanya alih generasi yang berkesinambungan; (3) kondisi perekonomian Indonesia yang tidak stabil, juga mempengaruhi keberlanjutan tari Balanse Madam.

Kondisi ekonomi yang tidak stabil tentu berpengaruh pada kelangsungan tari Balanse Madam, sebab setiap penampilan tari Balanse Madam ditandai dengan pemberian ayam utuh yang disebut manu bule atau ayam bulek ( lihat gambar 3) dari yang punya hajat kepada pemangku adat (kapalo kafo, tuo kafo, ninik mamak) sebagai oleh-oleh untuk dibawa pulang. Pemangku adat tidak berasal dari satu kampung saja, tetapi ada tujuh kampung yang disiapkan untuk oleholeh yang disebut uracha.

Ketiga faktor di atas mengarahkan kepada kerapuhan keberadaan tari Balanse Madam ditengah-tengah masyarakat pendukungnya. Kerapuhan ini mengundang keprihatinan bagi penggiat tari Balanse Madam di lingkungan masyarakat Nias, seperti Tawanto Karim (60 tahun). Namun dengan longgarnya aturan untuk para penari, yaitu sudah diperbolehkannya tari ini dimainkan oleh anak muda-muda, maka Tawanto meluangkan waktu untuk melatih tari Balanse Madam. Hal ini dapat dikatakan sebagai gerakan keberlanjutan bagi tari Balanse Madam. Namun jadwal latihan untuk tari Balanse Madam masih bersifat temporal. Artinya, latihan diadakan jika ada yang meminta penampilan tari Balanse Madam untuk hajatan.

Keberlanjutan tari Balanse Madam juga dapat dilihat

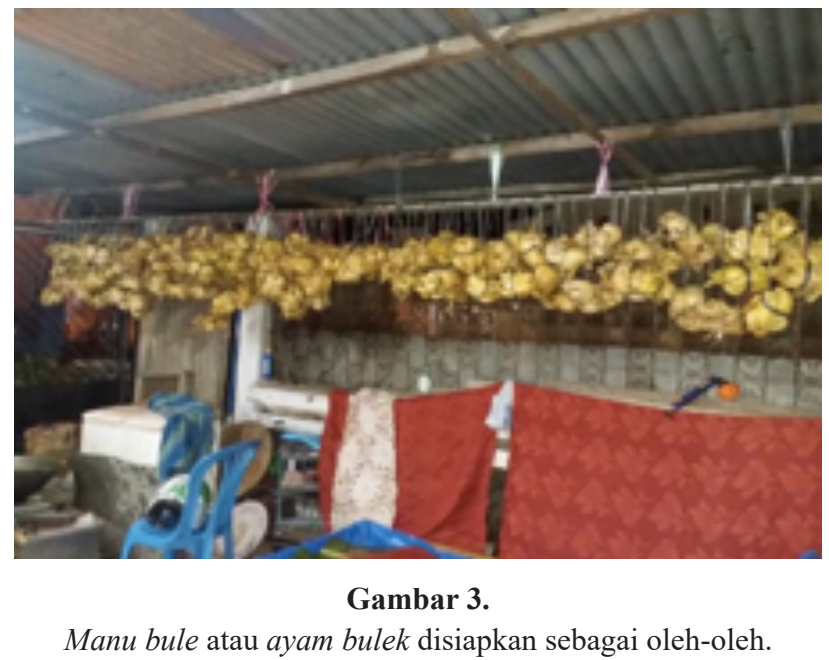

(Foto: Tawanto, 2016).

dari penggunaan musik rekaman berupa flashdisk, apabila pemain biola tidak dapat hadir untuk mengiringi penampilan tari Balanse Madam. Artinya, penggiat tari Balanse Madam seperti Tawanto berusaha mempertahankan keberadaan tari ini, agar tetap lestari sebagai kesenian yang khas dari masyarakat Nias Padang.

\section{SIMPULAN}

Perubahan yang terjadi pada tari Balanse Madam agaknya lebih cenderung karena faktor internal. Terjadinya perubahan faktor internal berasal dari kehidupan yang terkait dengan tari Balanse Madam. Perubahan faktor internal yang dimaksud adalah pada penarinya. Aturan sebelumnya penari harus orang yang sudah menikah, berubah menjadi pelaku tari yang masih remaja. Hal ini diakibatnya banyak penari Balanse Madam yang meninggal dunia dan sudah tuatua. Kemudian perubahan juga terjadi pada aba-aba yang diucapkan comander. Perubahan aba-aba ini diakibatkan karena jarangnya itensitas penampilan tari Balanse Madam dalam kehidupam masyarakat Nias Padang dalam setahun. Hal ini juga berdampak pada irama musik tari Balanse Madam. Meninggalnya pemain biola dan belum sempat mewariskan pola irama musik biola untuk dipelajari generasi mudanya, menjadikan irama musik biola tidak menjadi pemegang peranan penting dalam tari Balanse Madam. Irama musik biola hanya sebagai selingan dalam rangkaian iringan musik tari Balanse Madam. Permainan iringan musik tari Balanse Madam dimainkan secara live, terkadang pemain biola tidak dapat hadir untuk memainkan alat musik biola dan penggantinya juga tidak ada. Akibatnya iringan musik tari Balanse Madam menggunakan musik rekaman melalui media flashdisk. Perubahan yang terjadi terkadang dapat memberikan dampak positif demi keberlangsungan tari Balanse Madam. Sebagaimana yang dilakukan 
pada tari Balanse Madam, maka dibuat aturan yang longgar untuk para penarinya agar dapat dimainkan oleh anak-anak muda atau remaja dan penggunaan musik rekaman berupa flashdisk, sehingga keberlanjutannya dapat terjaga.

Arti kata keberlanjutan di sini, merupakan sebuah harapan terhadap kesenian yang unik seperti tari Balanse Madam tetap lestari di lingkungan masyarakat Nias Padang. Di dalam kondisi yang rapuh, dibuat aturan yang longgar, yaitu penari diperbolehkan bagi anak-anak muda. Kemudian kelangkaan pemain musik biola digantikan dengan iringan musik yang menggunakan orgen tunggal atau musik rekaman dari flashdisk. Namun kedepannya diharapkan kerjasama segitiga antara penggiat tari Balanse Madam dari masyarakat Nias Padang, peneliti/ pengabdian dosen dengan pemerintah kota setempat. Kerjasama tersebut adalah memberikan pelatihan dan pembinaan kepada generasi muda, sehingga diharapkan kedepannya pertunjukan tari Balanse Madam tetap eksis dimainkan dengan iringan alat musik barat dan tetap menghadirkan comander, sehingga tidak menghilangkan kekhasan dari tari Balanse Madam. Dengan demikian tari ini dapat hidup, tumbuh dan berkembang subur sebagai seni pergaulan tidak hanya di lingkungan masyarakat Nias Padang tetapi meluas pada masyarakat kota Padang.

\section{DAFTAR RUJUKAN}

Boskoff, Alvin. (1964). "Recent Theories of Social Change", dalam Werner J. Cahnman dan Alvin Boskoff (ed.) Sociology and History: Theory and Research. New York: Free Press of Glencoe.

Elina, Misda. (1997). "Pengaruh Musik Barat Terhadap Kesenian Balanse Madam dalam Masyarakat Minangkabau di Padang”. Tesis. Jurusan Ilmu Humaniora. Yogyakarta: UGM.

Kuntowijoyo. (1987). Budaya dan Masyarakat. Yogyakarta: PT. Tiara Wacana Yogya.

Maizarti.et. al. (1994). "Tari Balanse Madam di Kelurahan Seberang Palinggam Kotamadya Padang (Tinjauan Dari Pergeseran Fungsi)". Laporan Penelitian. Padangpanjang: STSI Padangpanjang.

Novina Yeni Fatrina.(2009). "Tari Balanse Madam Pada Masyarakat Nias di PAdang Sumatera Barat: Kajian Komparasi Bentuk". Tesis. Surakarta: ISI Surakarta.

Risnawati. (2002). "Tari Balanse Madam Dalam Masyarakat Nias di Padanh Sumatera Barat". Tesis. Jurusan Ilmu Humaniora. Yogyakarta: UGM.
Rizaldi. (1994). "Musik Gamat di Kotamadya Padang: Sebuah Bentuk Akulturasi Antara Budaya Peribumi dan Budaya Barat". Tesis. Jurusan Ilmu Humaniora. Yogyakarta: UGM.

Sedyawati, Edi. (1981). Pertumbuhan Seni Pertunjukan. Jakarta: Sinar Harapan.

(1986). Pengetahuan Elementer Tari dan

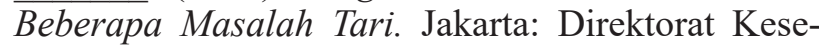
nian Proyek Pengembangan Kesenian.

(2007). Keindonesiaan Dalam Budaya:

Kebutuhan Membangun Bangsa Yang Kuat. Jakarta: Wedatama Widya Sastra.

Soedarsono, R.M. (1978). "Pengantar dan Pengetahuan dan Komposisi Tari". Diktat. Yogyakarta: ASTI.

Soekanto, Soerjono. (2012). Sosiologi Suatu Pengantar. Jakarta: PT. Raja Grafindo Persada.

Suharto, Ben. (1999). Tayub: Pertunjukan dan Ritus Kesuburan. Bandung : MSPI 